\title{
OBITUARY
}

\section{Rose Steinberg Stamler 1922 - 1998}

With the death of Rose Stamler after a long illness, cardiovascular medicine has lost an articulate advocate of public health, who, over a lifetime of research and teaching, had helped shape and promote a preventive approach to the burgeoning worldwide cardiovascular disease epidemic. Although nowadays the epidemiological principles underlying the preventive approach are widely accepted, this was by no means always the case. Even 10 or 15 years ago, epi demiologists had to fight (and win) difficult behind-the-scenes arguments to promote the population-wide strategy of risk-factor reduction. Rose Stamler was not afraid to challenge received wisdom and vested interests, whether in clinical medicine, industry or government. With her husband, Jeremiah Stamler, she played an important role in shifting the paradigm in clinical cardiology away from a focus purely on treatment of established disease, towards disease prevention. She was one of the founders and for many years coordinator and core faculty member of the Ten Day International Teaching Seminars on Cardiovascular Epidemiology and Prevention, held under the auspices of the International Society and Federation of Cardiology. This innovative programme has so far introduced around 1000 alumni from 80 countries around the world to the principles and practice of preventive cardiology. Her infectious humour, quick wit, generosity, deep humanity and high intelligence, endeared her to the many hundreds of friends and colleagues around the world who had had the good fortune to meet, work with, or be taught by her.

Rose Stamler (nee Steinberg) was born to immigrant parents in New York in 1922. She attended Brooklyn College from 1939 to 1941, until, following her father's sudden death from coronary heart disease, she gave up her studies in order to assist her mother in the family's stationery store. She continued her education as a night student at the City College of New York, and as an activist in the student movement, met her future husband, then studying medicine in New York.

Rose and Jeremiah Stamler were married in 1942. While he continued his medical studies, she took employment in a wartime production plant where she engaged in union activities (becoming a union organiser) for improvement of working conditions. Jeremiah Stamler joined the US army and after a per- iod of duty in Bermuda, they returned to New York and then to Chicago in 1948. Rose Stamler resumed her formal education, graduating from the University of Chicago in 1962 with a combined Bachelor of Arts/Master of Arts degree from the Department of Sociology. Her thesis 'Racial differences in heart disease factors - some socio-psychological aspects', was witness to her concern for health inequalities among the less privileged in society, and presaged much of her research that was to follow. Rose Stamler worked at the Population Center of the University of Chicago, the Cardiovascular Research Institute of Michael Reese Hospital, and the Chicago Health Department before joining Northwestern University Medical School in 1972 as assistant professor of preventive medicine. She graduated to a full professorship in 1987, and was Professor Emeritus of Preventive Medicine at Northwestern University at the time of her death.

Rose Stamler's research contribution spanned nearly 50 years, and she remained active in research until her final illness. From the mid-1950s to the early 1970s, she was engaged in the early surveys of the Chicago Heal th Department concerning coronary risk among low income populations, black and white, and was an investigator in large long-term prospective population studies such as the Chicago Heart Association Detection Project in Industry, the Chicago Western Electric and the Chicago Peoples Gas studies. She was involved in key multicentre trials of risk factor reduction, including the Hypertension Detection and Follow-up Program (HDFP), the Multiple Risk Factor Intervention Trial (MRFIT), the Systolic Hypertension in the Elderly Program (SHEP), the Primary Prevention of Hypertension Trial (PPH) and the Hypertension Control Program (HCP). Rose Stamler was Principal Investigator and lead author of the latter two studies. Their important results $^{1,2}$ were among the first to demonstrate that blood pressure control by nutritional-hygienic means, including lower sodium intake, reduction in obesity, increased exercise and lower alcohol intake, were effective both in the primary and secondary prevention of high blood pressure. In recognition of her original contributions on prevention of high blood pressure, she was invited as a member of the US National High Blood Pressure Education Program's Working Group on Primary Prevention of 
Hypertension, which reported in 1993. She also served influentially for many years as a member of the Public Policy Committee, American Heart Association of Metropolitan Chicago, and on US and international Councils on Epidemiology and Prevention.

Rose Stamler played a large and important role in the international co-operative INTERSALT Study of dietary electrolytes and blood pressure, carried out among over 10000 men and women in 52 population samples from 32 countries. She and I worked closely together, supported by the Study's Principal Investigators Jeremiah Stamler and Geoffrey Rose, to develop the Study's Manual of Operations (subsequently published in Controlled Clinical Trials ${ }^{3}$ ), to train the investigators in standardised methods during regional training sessions held around the world, to oversee data collection, and, with other members of the Study's Steering and Editorial Committee, to publish and disseminate the findings. She had primary responsibility for the INTERSALT report showing that the higher blood pressure levels of less educated strata of the population related significantly to higher salt and alcohol intake, higher body mass, and lower potassium intake. ${ }^{4}$ The INTERSALT Study called upon her many skills of diplomacy, tact, tremendous organising ability, and detailed knowledge and understanding of both the scientific issues and human nature. Despite the pressures associated with such a large undertaking, she was always calm, highly supportive, generous with her time, and above all warm, humane and very funny. Intense working sessions in her beloved Pioppi in Southern Italy (where she and her husband spent many fruitful months away from the cold of Chicago) would be interspersed with superb but simple Italian cooking and infectious good humour.

Rose Stamler also played a major role in the follow-on study to INTERSALT, the INTERMAP Study of macronutrients and blood pressure, which continues to this day with data collection, and to which she contributed right up until the last days of her life. The success of that study (dietary, blood pressure and urinary data collected so far on nearly 4000 individuals in four countries) owes much to her energies, vision and enthusiasm.

Rose Stamler had a huge personal commitment to training and helping junior colleagues, and to developing an international cadre of researchers based on an ethos of humane values and mutual respect. This was apparent not only through the energies she devoted to the International Teaching Seminars, but also in her international collaborations with other investigators, through the INTERSALT and INTERMAP studies, and especially with colleagues in Italy, Japan and in the People's Republic of China. Rose Stamler contributed importantly to the Gubbio and Cimitile studies in Italy, and her work in the People's Republic of
China, as part of the PRC-USA Cardiovascular and Cardiopulmonary Epidemiology Research Group, built on her long-standing support and encouragement towards the establishment of Iarge-scale popuIation studies in the PRC.

One other aspect of Rose Stamler's life and scientific contribution deserves special mention. She often was content to work 'behind the scenes' both in support of her husband, and in influencing important areas of policy where her own personal contribution may not al ways have been fully recognised in favour of the 'greater good'. Nowhere was her indefatigable pursuit of justice and fair play more apparent than when she (successfully) took up the fight against the Un-American Activities Committee who had issued a subpoena against her husband in 1965. The dissolution of that committee some 10 years later was in no small part due to her efforts.

Rose Stamler was a mentor, friend, and as someone who led her life by the highest principles, a tremendous example to all who knew her. In addition to her scientific activities, she found time to be a lover of music (especially M ozart and opera), a theatre-buff, an avid reader of both fiction and nonfiction and (as I can attest) an expert Scrabble player. She is survived by her husband, Jeremiah, her son, Paul, and her sister, Gertrude. She is greatly missed.

P Elliott London

\section{Acknowledgement}

The author is grateful to Professor J Stamler, Dr Darwin Labarthe and Dr Linda van Horn for biographical material collated as part of a celebration of Rose Stamler's life that took place at Northwestern University Medical School on 4 May 1998. Some of that material is also included in an appreciation of Rose Stamler to be published in CVD Prevention, the Journal of the International Society and Federation of Cardiology.

\section{References}

1 Stamler R et al. Primary prevention of hypertension by nutritional-hygienic means. Final report of a randomized, controlled trial. JAMA 1989; 262: 1801-1807.

2 Stamler $\mathrm{R}$ et al. Nutritional therapy for high blood pressure. Final report of a four-year randomized controlled trial - the Hypertension Control Program. JAMA 1987; 257: 1484-1491.

3 Elliott $P$, Stamler R. Manual of operations for "INTERSALT", an international cooperative study of the relation of sodium and potassium to blood pressure. Controlled Clin Trials 1988; 9: 1-118S.

4 Stamler R, Shipley M, Elliott P, Dyer A, Saro G, Stamler $\mathrm{J}$ on behalf of the INTERSALT Cooperative Research Group. Higher blood pressure in adults with less education: some explanatory factors. Findings of the INTERSALT study. Hypertension 1992; 19: 237-241. 